\title{
Europe and Southeast Asia: ASEAN-EU Interregionalism between Pluralist and Solidarist Societies
}

\author{
Noel M. Morada ${ }^{1}$ \\ 1 Asia Pacific Centre for the Responsibility to Protect, School of Political Science and International Studies, \\ University of Queensland St. Lucia, Brisbane, Australia \\ Correspondence: Noel M. Morada, School of Political Science and International Studies, University of \\ Queensland St. Lucia, Brisbane QLD 4072, Australia. Tel: 61-7-3346-6446. E-mail: n.morada@uq.edu.au \& \\ nmorada@gmail.com
}

Received: November 24, 2011 Accepted: April 26, 2012 Online Published: July 1, 2012

doi: $10.5539 /$ res.v4n3p89

URL: http://dx.doi.org/10.5539/res.v4n3p89

\begin{abstract}
This article examines ASEAN-EU relations using the framework of international society of the English School. Specifically, it attempts to examine the utility of pluralist and solidarist conceptions of international society in understanding the nature and dynamics of ASEAN-EU relations and the ASEM process. It argues that interregional relations between ASEAN and the EU have for the most part been determined by their identities as pluralist and solidarist societies, respectively, which is clearly manifested in their different perspectives and approaches on political, economic, and security issues. The EU is primarily considered a strategic partner of ASEAN in the latter's attempt to balance its relations with other external powers, particularly in dealing with rising power like China. However, their partnership remains narrow and shallow even as the EU is perceived mainly as a donor to ASEAN's socioeconomic development goals.
\end{abstract}

Keywords: ASEAN, ASEM, EU, human rights, regionalism, FTA

\section{Introduction}

Hedley Bull defines an international society as "a group of states, conscious of certain common interests and common values, form a society in the sense that they conceive themselves to be bound by a common set of rules in their relations with one another, and share in the working of common institutions" (Bull, 1977: 13). Bull has characterized the English School debates on international society as a dialogue between two competing conceptions: pluralism and solidarism. While they agree that the international society of states "includes commonly agreed values, rules, and institutions", the two camps, however, differ about the "normative content" of this society (Bellamy, 2005: 9-10). For pluralists, the normative content of an international society is "limited to a mutual interest in the continued existence of the units comprising the society...manifested in the reciprocal recognition of state sovereignty and the norm of non-intervention." Pluralists also argue that an agreement among states about issues like human rights and redistributive justice is not possible even as they believe that "moral and political codes" are rooted in specific cultural contexts and cannot be universal (Bellamy, 2005: 10). Solidarists, on the other hand, consider states in an international society as having agreement or solidarity "in developing and enforcing international law" and where the use of force is considered legitimate in order to enforce the law... and the upholding of the society's moral purpose" (Bellamy, 2005: 10). Solidarists point to the emergence of international human rights regimes, for example, as evidence for their argument that diverse communities are able to reach agreement on moral norms, which must be upheld by members of the society (Bellamy, 2005: 10-11).

The Association of Southeast Asian Nations (ASEAN) may be considered a pluralist international society given its traditional norms that underscore reciprocal recognition of sovereignty and non-intervention. It is the anchor of ASEAN's intersubjective systemic structure on which its collective identity has been formed. From a solidarist perspective, the European Union (EU) is a more developed international society that has established common policies, institutions, and legal frameworks from which its identity stems. This article examines ASEAN-EU relations using the framework of international society of the English School. Specifically, it 
attempts to examine the utility of pluralist and solidarist conceptions of international society in understanding the nature and dynamics of ASEAN-EU relations and the ASEM process. Given the historical relations between ASEAN and EU over the last three decades, has there been a set of shared values between the two regional organizations? To what extent have their identities determined or influenced the nature of their interregional relations? This article argues that the interaction between ASEAN and the EU may be characterized as one between two communities that have different conceptions about the normative content of their interregional relations. This is basically due to differences in their identities and roles as international societies, which to a large extent stem from their different levels of political and economic development. It focuses on how the EU/Europe is perceived in Southeast Asia in the context of both the ASEAN dialogue and ASEM process. More specifically, the article looks into how the interaction between the two communities or societies have evolved over time and examine how issues concerning human rights, regional security, and economic development have shaped their relations. What follows is a brief background to ASEAN-EU relations and the ASEM process.

\section{Overview of ASEAN-EU Relations}

The member states of ASEAN consist of former Western (European) colonies in Southeast Asia. ASEAN was formed in 1967 or more than a decade after the first European community (Euratom) was set up. Regionalism in Western Europe and Southeast Asia started in the context of preventing conflicts: in Europe after the Second World War and the Southeast Asia following inter-state conflicts that came after the period decolonization and independence. One important difference in the European and Southeast Asian approaches to regionalism is that the former adopted the framework of supranationalism, where member states surrender part of their sovereignty to a new center of authority (i.e. European institutions), whereas the latter embarked on regional cooperation in an effort to protect and uphold sovereignty of members, which is enshrined in the Treaty of Amity and Cooperation (TAC) in 1976. Even after the Vietnam War in 1975 and the Vietnamese invasion of Cambodia in 1978, ASEAN's main preoccupation was still about protecting the territorial integrity of its members. It was only after the political settlement of the Cambodian conflict in 1991 that ASEAN started to focus substantively on deeper economic cooperation, which became even more critical following the Asian financial crisis of 1997-1998. More importantly, the rise of China as an economic power even served as in impetus for the creation of an ASEAN Community, which was launched in 2003 under the Bali Concord II and envisions ASEAN as a single investment and production hub that could compete with China and even India. An important pillar of the ASEAN Community is the creation of a "just, democratic, and harmonious environment" where member states share a set of norms and continue to be engaged in norm building in the region (ASEAN 2003 Bali Concord II).

\subsection{ASEAN-EU Cooperation before 1994}

The European Economic Community (EEC) was one of ASEAN's first dialogue partners. Informal dialogue was established in 1972, which was primarily aimed at gaining access to European markets for most ASEAN members' exports. Relationship between the two regional organizations was elevated to a higher level with the first ASEAN-EC Ministerial Meeting (AEMM) in 1978, which later became a regular meeting. The first ASEAN-EC Cooperation Agreement was signed in Kuala Lumpur in 1980, which focused on economic cooperation and development. Specifically, the Agreement extended a so-called Most Favored Nation (MFN) treatment to the contracting parties and paved the way for EC's participation in a number of ASEAN development projects (Yeo, 2003: 21). The Agreement was also perceived by some scholars in Southeast Asia as according ASEAN legal personality and recognizing its identity as an important actor in promoting regional peace and stability (Robles, 2004: 20). Notwithstanding this Agreement, however, ASEAN remained low in the priority of the EC's external relations vis-à-vis the African, Caribbean and Pacific (ACP) and Latin American countries. As the largely symbolic significance of the Agreement waned, ASEAN began to "turn to the EC for material support for regionalization" (Robles, 2004: 20). The relationship between the two blocs was seen pretty much as "donor-recipient" ties as ASEAN focused on getting more development assistance, better market access, and technology transfers from the EC. The unequal relationship was also exploited by ASEAN members collectively and individually to attract more European interest in trade and investments, which resulted in steady growth of interregional economic transactions. Even so, the relative importance of ASEAN to the EC remained unchanged (Yeo, 2003: 21).

The early 1990s saw the launching of the ASEAN Free Trade Area (AFTA) and the ASEAN Investment Area (AIA) in response to growing competition from China and other emerging markets (Yeo, 2003), which became the precursors to the ASEAN Economic Community in 2003. These projects seem to have encouraged a number of European firms to consider Southeast Asia not just as a market for Europe but also as a production base that could open opportunities for joint ventures with firms in the region (Robles, 2004). To some extent, ASEAN was relentless in attempting to persuade the EU that peace and stability in Southeast Asia and embarking on AFTA 
and AIA would "provide a secure and profitable environment for European direct investments" (Yeo, 2009). With the eventual expansion of the group to 10 members, ASEAN no doubt would become a more attractive market for the Europeans and thus enhance further the organization's confidence that it will be an important link to wider Asia-Europe relations. This was also in the minds of key EU members who wanted to focus on economic ties with ASEAN rather than on sensitive political issues that emerged in the early 1990s, which easily dovetailed with the shift in the EU's policy towards Asia as reflected in the July 1994 "Towards a New Asia Strategy" of the EC Communication(Yeo, 2009).

Political cooperation between the two regional organizations became closer in the 1980s as their strategic interests converged over Vietnam's invasion of Cambodia and the former Soviet Union's invasion of Afghanistan. Both blocs coordinated their votes in the UN on these issues, which also dominated discussions in the AEMMs for a decade (Yeo, 2003: 22). However, in the aftermath of the Cold War, relations between ASEAN and EC began to sour as the latter started focusing on human rights and democratization. Specifically, the strong reaction of the European countries against the violence in East Timor in 1991 and the EU's policy of linking development assistance to improvements in human rights and promotion of democracy to some extent strained ASEAN-EC relations (ibid.). In the meantime, ASEAN attempted to re-structure its engagement with its dialogue partners as part of dealing with the uncertainties of the post-Cold War environment. The Post-Ministerial Conference (PMC) became the main framework for regular interaction with the traditional partners of ASEAN, which was held annually after the ASEAN ministerial meeting. This also paved the way for engaging "non-likeminded" states - such as Russia, China, North Korea and Vietnam (which was then not yet a member of the organization) - in regional security dialogue through the ASEAN Regional Forum (ARF), which was created in 1994.

From the foregoing discussion, it is clear that before the 1990s, the EU did not seriously pay attention to ASEAN as an emerging regional organization given that ASEAN member states did not share a common set of political values even as they also competed for assistance, trade, and investments from Europe. Indeed, ASEAN during this period was far from having consciously thought of itself as a society of states that needed to embark on community-building efforts and follow the path of the EU. While ASEAN may have been recognized by the EU as playing a significant role in promoting peace and stability in Southeast Asia, this was largely based on shared Cold War perspectives as well as its acknowledged diplomatic role in the Cambodian conflict where it demonstrated unity in denying legitimacy to the Vietnamese-installed government in Phnom Penh both in the UN. After the 1991 Paris Peace Agreement that put an end to the Cambodian conflict, ASEAN's identity as a coherent regional actor was pretty much in doubt. With the end of the Cold War, ASEAN was forced to look for a new raison d'etre even as the wave of democratization was sweeping across the region following the "people power" uprisings in the Philippines (1986) and Thailand (1992), including the one aborted by the military in Burma/Myanmar in 1990. In order to stave off this challenge, authoritarian ASEAN member states led by Singapore and Malaysia put forward the "Asian values" defense against "onslaught" of Western liberalism in the region. That this should be the impetus for ASEAN emerging as a pluralist society of states became more evident in the way that some of its members underscored the importance of traditional norms (mutual respect for sovereignty and non-interference) and in dealing with the EU on human rights issues. Specifically, it manifested this pluralist identity when it protested the EU's policy of linking external assistance to developing states with improvement in human rights and democracy, and later on in parrying criticisms from the Europeans about the admission of Burma/Myanmar as a member of ASEAN in 1997.

\subsection{Milestones in ASEAN-EU Relations since 1994}

The $11^{\text {th }}$ ASEAN-EU Ministerial Meeting in Karlsruhe, Germany, in September 1994 marked an important turning point in relations between the two blocs. The meeting created an Eminent Persons Group (EPG) tasked to develop a more comprehensive approach to ASEAN-EU relations in 2000 and beyond, which led to convening the first ASEAN-EU Senior Officials Meeting (SOM) in Singapore in 1995. A second SOM in Dublin, Ireland, in 1996 followed where sensitive issues such as human rights, democracy and Myanmar's membership in ASEAN were also discussed. The New Asia Strategy and the Karlsruhe statement both declared that ASEAN would remain the cornerstone of the EU's engagement with countries in Asia. This set the stage for convening the Asia Europe Meeting (ASEM), with its first inaugural Summit held in Bangkok in March 1996 and the first ASEM Foreign Ministers Meeting in Singapore in February 1997. In July 1996, the EC released another Communication on "Creating a New Dynamic in EU-ASEAN Relations", which reaffirmed its New Asia Strategy and its commitment in strengthening ties with ASEAN as one of the key elements in the EU's Asia policy. More specifically, the EC regarded ASEAN as both political interlocutor and engine of the new Asia-Europe dialogue (ASEAN, 2009). In the $12^{\text {th }}$ AEMM in Singapore in 1997, a Joint Declaration considered 
by ASEAN as a forward-looking document incorporated many of the initiatives made in the Karlsruhe meeting. Apparently, however, the ideas and recommendations contained in many of these documents did not result in concrete measures and contributed to a plateau in ASEAN-EU relations towards the turn of the $21^{\text {st }}$ century. A number of factors also had an impact on interregional relations, namely, the Asian financial crisis in 1997-1998, the creation of ASEM, and the expansion of ASEAN and EU memberships. Together with important changes in the global context (e.g. 9/11 and the American invasion of Iraq in 2003), the confluence of these events and factors apparently exerted pressure on the ASEAN and the EU to revitalize their partnership (Yeo, 2009: 49).

In 2003, the EC Communications' "A New Partnership with Southeast Asia" basically outlined the strategic priorities of the EU's relations with ASEAN. This includes: 1) supporting regional stability and the fight against terrorism; 2) promoting human rights, democracy, and good governance; 3) mainstreaming justice and home affairs issues; 4) injecting a new dynamism into regional trade and investment relations; 5) continuing support for the development of less prosperous countries; and 6) intensifying dialogue and cooperation with specific sectors (EC Communications, 2004). The EC proposed in particular the creation of the Trans-Regional ASEAN-EU Trade Initiative (TREATI) that aims to expand trade and investment flows between the two regions, as well as to facilitate dialogue and regulatory cooperation on trade facilitation, market access, and investment issues between the two blocs. To some extent, the TREATI proposal from the EU was in response to the launching of the three-pillar ASEAN Community (Yeo, 2009: 53). For non-trade issues, the Regional EC-ASEAN Dialogue Instrument (READI) was set up in 2005, which covers transport, home affairs and justice concerns (e.g., human trafficking, transnational crimes, and money laundering), and the environment. In supporting the process of regional integration in Southeast Asia, the ASEAN-EC Project on Regional Integration Support (APRIS) framework was adopted to assist especially the less developed members of ASEAN. Along with the EU's participation in the Initiatives for ASEAN Integration (IAI), APRIS is expected to contribute to narrowing the development gap among ASEAN members, which consequently would promote further regional economic integration (Yeo, 2009: 54).

\subsection{Nuremberg Declaration on Enhanced ASEAN-EU Partnership}

In March 2007, at the $16^{\text {th }}$ AEMM in Nuremberg, Germany, the foreign ministers agreed to pursue enhanced partnership between the two blocs. The Nuremberg Declaration specifically identified five areas of cooperation: political security, economic, energy/climate change/environment, socio-cultural, and development (ASEAN, 2007a). Subsequently, a Plan of Action (POA) was drawn up to serve as a master plan for five years (2007-2012) specifically to support the goal of achieving the ASEAN Community by 2015, in accordance with the Vientiane Action Plan and the Bali Concord II. For political-security cooperation, some of the activities planned were: 1) the EU/EC's accession to the TAC; 2) institution/capacity building in regional cooperation; and 3) various seminars and workshops related to some issue areas in the ARF (e.g. CBMs, preventive diplomacy, anti-personnel landmines, small arms and light weapons). In the area of economic cooperation, some activities proposed include advancement of the ASEAN-EU FTA negotiations (ASEAN, 2007b). Apparently, a regional ASEAN-EU FTA cannot be pursued at this time for various reasons (e.g. Myanmar issue and development gaps in ASEAN) and the best alternative is to negotiate bilateral FTAs with individual ASEAN member states, starting with Singapore. As a prelude to bilateral FTAs with members of ASEAN, a Partnership Cooperation Agreement (PCA) must first be negotiated that should contain a commitment to promotion and protection of human rights. So far, Indonesia and the Philippines have signed or initialed PCA agreements with the EU, while Malaysia, Thailand, Vietnam, and Brunei are still in various stages of PCA negotiations. In the case of Malaysia, it is reportedly negotiating bilateral PCA and FTA with the EU at the same time.

Evidently, ASEAN's decision to embark on its community building project in 2003 fostered the EU into giving ASEAN more serious attention. This stems primarily from the ASEAN Community's goal of transforming the organization into a more "rules-based" and people-oriented community, where regional integration, democracy, good governance, and human rights protection have been incorporated in its pillars. Certainly, the EU was interested in the ASEAN Economic Community (AEC) pillar, which aims to transform ASEAN as a production and market hub in the region as part of the organization's strategy to attract investments. But even more significant for the EU are the ASEAN Political Security Community (APSC) and the ASEAN Social Cultural Community (ASCC) pillars which focus on norm building and the promotion of human rights, democracy and good governance, as well as narrowing the development gaps in ASEAN. To some extent, the ASEAN Community project may be seen as an attempt on the part of ASEAN not only to deal with the economic challenges posed by globalization in general and the rise of China in particular but more importantly to start conforming - even in an evolutionary manner - to international norms related to democracy, human rights, and good governance. The adoption of the ASEAN Charter in 2008 - which includes principles of human rights 
protection and paved the way for the creation of the ASEAN Intergovernmental Commission on Human Rights in 2009-to some extent manifests how serious ASEAN is in realizing the APSC, at least for democratic member states pushing this agenda like Indonesia and the Philippines. Given the diversity of ASEAN members' political systems, however, this project would not necessarily alter the regional organization's pluralist identity in the near future. Indeed, tensions in ASEAN-EU relations would still continue in the area of political cooperation given that most ASEAN members have not completely abandoned the organization's traditional norms.

\section{Asia Europe Meeting (ASEM)}

The inaugural Summit meeting of ASEM was held in Bangkok in March 1996 attended by heads of states and governments from Asia (ASEAN, China, Japan, and South Korea) and 15 EU member states and the EC. After the Bangkok meeting, several biennial summits were held alternately between Asia and Europe: London (1998), Seoul (2000), Copenhagen (2002), Hanoi (2004), Helsinki (2006), Beijing (2008), and Brussels (2010). To date, there are already 48 partners in the ASEM process, composed of 19 Asian and Pacific countries (including Australia and New Zealand), 27 EU members, the ASEAN Secretariat, and the EC.

\subsection{Rationale, Impetus, and Contexts}

A number of factors have contributed to the formation of ASEM to wit: 1) the growing economic dynamism of East Asia (ASEAN and the three Northeast Asian countries); 2) deepening regional integration in Europe; 3) the formation of the Asia Pacific Economic Cooperation (APEC) largely upon the initiative of the United States to promote trade among the economies of Pacific rim countries; 4) the end of the Cold War, growing economic competition between regions; 5) the increasing interdependence between Asia and Europe; 6) the unilateralist tendencies of the United States; and 7) the perceived need to engage an emerging China in the international system. To some extent, the growing confidence of East Asian countries, the reaction to APEC by European countries and to NAFTA by Asian states, as well as fears of an emerging "fortress Europe" also served as impetus to ASEM's creation. More importantly, of the three regions that are considered as the "engines of global economy" - America, Asia, and Europe -the relationship between Asia and Europe was much weaker in comparison to trans-Atlantic and Asia-Pacific regions. This undoubtedly provided the strategic rationale for creating ASEM (JCIE and University of Helsinki, 2006: 4; Yeo, 2003).

Yeo (2003) gives credit to Singapore and ASEAN in the creation of ASEM. Specifically, she pointed out that, "without the initiative by Singapore prime minister Goh Chok Tong and the role played by ASEAN, ASEM might not have got off the ground in such a short time" (Yeo, 2003: 17). It was in Singapore that the need to "complete the triangular balance between the three engines of the world economy" was developed based on the speeches of Prime Minister Goh and Senior Minister Lee Kuan Yew in the World Economic Forum/East Asia Economic Summit in 1994. The timing of the proposal was also most auspicious as the EC in July 1994 called on the EU to accord higher priority to Asia in its external policy, as contained in its "Towards a New Asia Strategy" (Yeo, 2003: 19). For its part, the rest of ASEAN supported Singapore's idea in its inter-regional meetings with the EU and the ASEAN-EU framework served as a model for the ASEM process. From the perspective of ASEAN's long term strategy, ASEM would also besuitable in encouragig the presence of the EU in East Asia as part of having more powers in the region, which could then reduce the likelihood of any single power dominating the area (Yeo, 2003: 20).

\subsection{Goals, Principles and Structures}

In its first Summit meeting (ASEM1) in Bangkok, the Chairman's Statement identified a number of goals of the ASEM, which are to: 1) strengthen political dialogue; 2) enhance existing dialogues on general security issues through ASEAN-EU ministerial meetings, the ASEAN Regional Forum and ASEAN post-ministerial meetings; 3) promote the effective reform and greater democratization of the UN; 4) pursue systematic and progressive efforts to reduce nuclear weapons globally; 5) generate greater trade and investment flows between Asia and Europe; 6) strike an economic partnership based on common commitments to the market economy, an open multilateral trading system, non- discriminatory liberalization and open regionalism; 7) work towards a common World Trade Organization (WTO) agenda at its first ministerial meeting in Singapore; 8) intensify science and technology exchanges, particularly in agriculture, information technology, energy and transport, and to strengthen cooperation in education and training; 9) improve development cooperation with priority given to alleviating poverty, promoting the role of women and combating AIDS; and 10) cooperate in combating drug trafficking, money laundering and illegal immigration (ASEM, 1996).

At ASEM2 in London in 1998, leaders agreed that the ASEM process should be: 1) conducted on a basis of equal partnership, mutual respect and mutual benefit; 2) an open and evolutionary process - enlargement should 
be conducted on the basis of consensus by the heads of state and government; 3) enhance mutual understanding and awareness through a process of dialogue that will lead to cooperation on the identification of priorities for concerted action; and 4) carry forward the three key dimensions of the relationship - fostering political dialogue, reinforcing economic cooperation and promoting cooperation in other areas - with the same impetus (ASEM, 1998). These principles were later incorporated into the AECF at ASEM3 in Seoul in 2000, with two additional principles, to wit, that the ASEM process should 1) not be institutionalized and that, as an informal process, ASEM should stimulate and facilitate progress in other fora, and 2) go beyond governments in order to promote dialogue and cooperation between the business/private sectors of the two regions and, no less importantly, between the peoples of the two regions; ASEM should also encourage the cooperative activities of think-tanks and research groups of both regions (JCIE and University of Helsinki, 2006: 4-5).

Clearly, ASEAN's pluralist identity has also influenced the ASEM process. This is manifested in the way that ASEM has adopted the evolutionary and non-institutional approach and consensus decision-making process in its development, which are patently ASEAN's way of engaging with its dialogue partners. At the same time, ASEAN is protective of its centrality in ASEM as it underscored at the outset the importance of enhancing ASEAN-led frameworks such as the ASEAN-EU dialogue mechanism, the ARF, and ASEAN-post ministerial meetings as one of the important goals of the ASEM process. By ensuring its centrality in regional dialogues and security architectures, ASEAN as a bloc of less powerful states is able to manage its relations with extra-regional powers. That ASEAN wanted the EU's presence in Asia to balance these other major powers is also part of ASEAN's hedging strategy in the region, particularly in dealing with the rise of China.

\section{Europe in the Eyes of Southeast Asia}

How is the EU perceived in Southeast Asia and to what extent is the EU regarded as an important "other" by elites and the general public in ASEAN and the rest of ASEM? The detailed discussions below indicate that the EU is considered mainly as an economic power, but one with limited normative and political influence at the global level. It is also not highly regarded as an important partner compared to the United States or China given the more intense level of interaction of these two powers in the region. Corollary to this is the perception that the EU has thus far neglected ASEAN in favor of rising China and India (Yeo, 2003). The state of relations between the two regional organizations remains narrow in scope and lacking in depth, and one that remains asymmetrical in favor of the EU. The EU's support for regional integration in, and the desire to enter into a FTA with, ASEAN has been viewed by some scholars as driven primarily by economic interests that would be more advantageous to the EU (Robles, 2008 a, b). Meanwhile, good governance issues, in particular human rights and democracy, have significantly shaped the interaction of ASEAN-EU relations and the ASEM process (Manea, 2008). It is in this area where the process of collective identity formation of ASEAN developed vis-à-vis the EU, especially in the context of controversies surrounding East Timor (prior to its independence from Indonesia) as well as Myanmar/Burma.

\subsection{The EU as International Actor}

A comparative study published in 2007 and 2009 by the Asia Europe Foundation (ASEF) about Asian perceptions of the EU across eight East Asian countries (that includes five members of ASEAN) indicate that elites in the region perceived the EU mainly as an economic power, but with varying degrees of appreciation for its political and normative influence globally. In general, the EU was rated poorly as a military power especially when compared with the United States. Other significant results of the study show that: 1) the EU as an international political actor was common in the media coverage across eight countries, with most news covering Iran's nuclear issue, the Middle East, and EU-China relations (except in South Korea, Japan, and Thailand focusing on the Korean nuclear issue); 2) traditional perceptions of the EU as an economic actor still persists in media coverage, accounting for $47 \%$ (in 2006) and $45 \%$ (in 2008) compared to $39 \%$ (2006) and $35 \%$ (2008) of news about EU as a political actor; 3) public opinion indicate that the EU is ranked well below the US and China as being an important foreign partner either currently (between fourth to seventh place) or in the future (between fourth and fifth place); 4) respondents in Thailand (72\%), Indonesia (59\%), and Vietnam (56\%) considered economic issues to be kept in mind in negotiating bilateral relations with the EU compared to Singapore (36\%) and the Philippines (34\%); and 5) less than $20 \%$ of respondents across the region indicated that political issues should be kept in mind in bilateral negotiations with the EU (Holland, 2009: 133-138, 146-148, 152-153).

The EU as a "social", "environmental", or "developmental" actor were also covered in the study, which indicate that: 1) media coverage of the EU's actions in social, environmental, and developmental affairs were only $13 \%$, $4 \%$ and $1.6 \%$, respectively across the region compared to political (35\%) and economic (45\%) issues; 2) public opinion about the "stereotypical image" of the EU did not associate it with characteristics such as "social affairs 
champion," an "environmental champion," or a "developmental trendsetter"; and 3) it is only in the Philippines where public opinion of the EU was linked to the administration of developmental aid, which correlates highly with media coverage in the country of social development issues. It is interesting to note that despite low media coverage in Indonesia and Vietnam about democracy, good governance, and rule of law, these issues scored high in "spontaneous associations" of the EU in public opion survey in these two countries (Chaban, 2009: 171, 204-206).

\subsection{Assessments of ASEAN-EU Relations and ASEM}

There is no question that relations between ASEAN and the EU leaves much to be desired. For one, the scope of their ties remained narrow and focused mainly on trade, investments, and development cooperation (Robles, 2004: 169). The relationship has also been asymmetrical in favor of the EU although this did not predetermine the outcomes of its interactions with ASEAN even as the latter also invested time and resources to gain concessions from the EU (Robles, 2004: 169-170). With regard to negotiations for a free trade agreement with the EU, member states of ASEAN are not likely to substantially benefit from it if the former's failed FTA negotiations with other regions are any indication. Robles (2007a, 2007b, 2008b, 2008c) has consistently argued that ASEAN should learn from failed negotiations with the South African Development Community (SADC) and Mercosur. Specifically, a FTA with EU would not necessarily promote European FDI because "the competitiveness of European goods, accompanied by European protection for sensitive sectors, means that an (sic) FDI would risk increasing the region's trade deficits with the EU, undermining local industries, and hampering efforts to enhance competitiveness of local firms" (Robles, 2008c: 194). Hence, he questions the rhetoric of the EU that it is a "natural supporter of regional integration among developing countries,and that its goals in doing so are political rather than economic" (ibid.).With regard to the ASEM process, Robles (2008a) argues that it has not achieved its main function as a forum for dialogue, especially in the areas of economic and social development or economic cooperation; and, although it was the EU that insisted on including political issues as part of the ASEM dialogue agenda, it also faced a dilemma in reconciling their economic and political interests (Robles, 2008a: 163-169). For him, the path to making progress in ASEM is not through either institutionalization or interregionalism, but through a combination of several levels of governance between Asia and Europe, and that cooperation should not be limited to the ASEM framework. This is also based on the European practices of "variable geometry and multi-speed" approach, which could cover a range of issues (e.g. economic, trade, social development, human rights, political and security) (Robles, 2008a: 170). Based on these assessments, the structure of ASEAN-EU relations remains beneficial for Europe more than Southeast Asia and the prospects for a more institutionalized interaction between the two regions remain weak.

For her part, Yeo (2009) thinks that ASEAN-EU relations and ASEM face a number of challenges, especially in the area of political cooperation. Specifically, the regional contexts in both the ASEAN and the EU do not seem to be conducive to moving the interregional relationship at a much deeper and meaningful level. For example, notwithstanding the formal rhetoric in the EU, Asia is still not considered central to the EU's interests, except for rising China and India, and to the detriment of Southeast Asia (Yeo, 2009: 52). ASEAN, on the other hand, is back in its old "ASEAN Way" after a short period of enthusiasm for developing a rules-based community, reform of ASEAN structures, norms, and institutions that are supposed to enhance regional integration in the region. She then raises questions about whether ASEAN is able to continue driving the regional community building efforts even beyond Southeast Asia (Yeo, 2009: 53). In her assessment,

"Southeast Asia as a region continues to be neglected in EU strategic considerations. Using interregional (EU-ASEAN) and trans-regional (ASEM) dialogues may have served well in building symbolic and diplomatic ties, but this has not translated into a coherent strategy for long-term cooperation. In some cases, dialogues become prisoners of their own rules. For example, it is frustrating that the Myanmar issue, as important as it is, can be allowed to derail EU cooperation with ASEAN and the ARF. With little progress in sight for reforms the 'Myanmar problem' is again likely to dominate EU-ASEAN relations for some time" (Yeo, 2009: 54-55).

In order for ASEAN-EU relations and ASEM to substantively move forward, Yeo argues for setting long-term agenda through existing mechanisms that are already in place (e.g., TREATI, READI and APRIS). For her,

"the practical way forward is to allow relations to be project-driven rather than meeting-driven. Beyond dialogue, there must be some concrete deliverables: information sharing and capacity building to help fight terrorism; programmes for human resource development: whether in skills training, business education or in general higher education; 
environmental programmes for Southeast Asia aimed at providing sustainable development; and poverty alleviation programmes to help ASEAN countries achieve its Millennium Development Goals" (Yeo, 2009: 55).

These suggestions clearly indicate that ASEAN states still look up to the EU as significant source of assistance for promoting social and economic development in the region. This basically reflects the fact that the traditional "donor-recipient" ties that characterized the early stages of ASEAN-EU relations in the early 1980s have not yet been fully transformed into a more equal partnership between the two regions.

Apart from the above scholars' works, policy-oriented think tanks in the region have also come up with their own assessment of ASEM. Specifically, the Japan Centre for International Exchange (JCIE) and the University of Helsinki in 2006 published a report that at the time evaluated ASEM's existence for the past 10 years, with JCIE coordinating the research of several policy-oriented research institutions in some ASEAN countries and in China, Japan, and South Korea. Among the essential findings of both the Asian and European teams about ASEM were as follows: 1) the dialogue process has been broad but not deep, and has been mainly at the information-sharing level; 2) it has been lagging in concrete achievements; 3) its relevance in the broader international context has been questioned as it has not contributed to the triangular balance of power remarkably; 4) it has failed to efficiently harmonize the interests of its partners vis-à-vis larger international organizations and bodies; and 5) its lack of concrete achievements stems from issues about principles and objectives and constraints related to management and coordination. (JCIE and University of Helsinki, 2006: 7) Despite these weaknesses, however, the report argued that ASEM is still important for both Asia and Europe as it provides a "unique dialogue forum" for the two regions. It also pointed out that ASEM's principles and objectives, as well as its modus operandi "must be evaluated and clarified to bring it more in line with the ideal and objectives of close interregional cooperation." (JCIE and University of Helsinki, 2006: 12)

The media in the region have also made some assessments about ASEM, which was covered in the ASEF study published in 2007 and 2009 cited earlier. Specifically, coverage of ASEM6 and ASEM 7 "attracted positive attention for its achievements in the growth of inter-regional trade; for widening the geopolitical dialogue, raising mutual awareness and understanding between Asia and Europe; for facilitating various multilateral fora; and for the promotion of regional cooperation in East Asia." ASEM was also given credit for "facilitating bialteral ties between individual participating states." (Yi \& Chaban, 2009: 241-242) Some critical remarks in Asian newspapers about ASEM include the process being "'long on talk but short on substance', specifically when it came to the commitment on climate change and human rights abuses in North Korea and Myanmar." With regard to ASEM6, for example, some saw the meeting as "a failure in building consensus among its participants" because of the lack of coherence between ASEAN and the EU. (ibid.)

\subsection{Dialogue on Human Rights and Democracy}

Human rights and democracy have been contentious issues in ASEAN-EU relations and the ASEM since the early 1990s. Tensions in interregional relations centered on East Timor (prior to its independence from Indonesia) and Myanmar/Burma following its admission into ASEAN in 1997. To some extent, the interregional dialogue with the EU on human rights stimulated the regional identity formation of ASEAN (Manea, 2008). Using Wendt's (1994) three causal mechanisms, Manea argues that ASEAN-EU and ASEM dialogues on human rights contributed to collective identity of ASEAN. First, ASEAN was engaged in strategic mode of interaction with the EU on this issue through rhetorical argumentation, which avoided the breakdown of their relations (Manea, 2008: 373). Second, systemic processes also contributed to ASEAN's collective identity via increased density of intra- and interregional interactions on human rights from the early 1990s, which in turn led to transnationalization of human rights discourses and agenda (Manea, 2008: 373). Another indicator of the systemic process was the emerging view that considers the EU as a "normative common other," which allows ASEAN to look at the European Union as "an alternative model" not only in terms of creating regional human rights policy but also for community building in Southeast Asia that could either be emulated or rejected (Manea, 2008: 374).

Third, intersubjective systemic structures of ASEAN also contributed to its identity formation, which evolved over time following the end of colonialism and during the Cold War. Specifically, this refers to "a philosophy of operation and cooperation based on a collection of principles, rules, and norms which were rooted in international standards and a political philosophy in tune with the domestic concerns" of its member states (Manea, 2008: 389). Indeed, ASEAN had developed its own norms and way of doing things, often referred to as "the ASEAN way", composed of core principles such as mutual respect for independence, sovereignty, non-interference, and peaceful settlement of conflicts among others. These traditional norms or principles, 
however, faced new challenges following the expansion of ASEAN in the mid-1990s and the desire for deeper regional integration through a "rules-based" ASEAN community (Manea, 2008: 390). The latter was precipitated by a number of events in the region, such as the Asian financial crisis in 1997 and the rise of China. In the course of operationalizing the idea of an ASEAN Community, which was launched in 2003, human rights protection emerged as an important issue within ASEAN following consultations with non-state actors in the region on the contents of the ASEAN Charter, the drafting of which was completed in 2007 and ratified in 2008. The Charter included a provision for the creation of a regional human rights body that was later established in 2009: the ASEAN Intergovernmental Commission on Human Rights (AICHR). To some extent, the transformation of ASEAN's views and more accommodating attitude on this issue maybe partly attributed to the process of interregional and intra-regional dialogues with the EU, together with the changing environment and dynamics in Southeast Asia following the Asian financial crisis in 1997. For one, the emergence of non-traditional security issues - e.g., pandemic diseases, haze, climate change, transnational crimes, etc. - forced many in ASEAN to recognize the limits of defending its traditional norms in the face of region-wide problems that affect many if not all its members (Dosch, 2003). As well, people-centered concepts like human security, human development, and good governance have become en vogue since the late 1990s, which eventually found their way into the official language of ASEAN as evidenced by various official documents and plans of action across the three pillars of the ASEAN Community.

Overall, it is evident that the EU and ASEAN are far from sharing a set of common political values even though both recognize each other's strategic role in the region. Specifically on the issue of human rights and the problem of Myanmar and North Korea, a gap still exists between the two organizations. This is not to say however that the EU has not succeeded to some extent in influencing ASEAN members in accepting people-centered norms and principles such as democracy, human security, and good governance. The fact remains, however, that ASEAN is still sensitive to these ideas as most of its members are defensive of the group's traditional norms. Whereas the EU, as a solidarist society, adheres to the belief that these principles are universal, ASEAN's pluralist identity would still underscore the importance of tolerating variations in the level of political development of member states when it comes to these matters.

\section{Conclusions}

In the context of ASEAN-EU relations and the ASEM process, it is clear that Europe's postcolonial presence in Southeast Asia is perceived primarily in economic terms. The EU is considered mainly as an economic power that could assist ASEAN in narrowing the development gap within the region. This perception stems mainly from the role played by the EU as a donor in the early stages of its relations with ASEAN. It is also viewed as a model for regional integration from which ASEAN could draw lessons from given its more advanced set of institutions and rules governing its member states. The EU is also considered as an important trading partner of ASEAN, notwithstanding difficulties in negotiating a FTA between them. As it is, trade relations between ASEAN and the EU remains asymmetrical in favor of the latter. Meanwhile, the EU's political and military influences however are not been given much weight by elites and the general public in Southeast Asia relative to other powers like China and the United States that have more clout in these areas. Nonetheless, ASEAN views the EU as an important actor in managing regional and global security issues, particularly in areas such as non-proliferation, transnational crime, and even human security.

As a more advanced and solidarist international society, the EU has had tensions in its relations with ASEAN, particularly in the area of promoting human rights norms in the region. As a pluralist community or society of states, ASEAN has adhered to its traditional norms that emphasize mutual respect for sovereignty and non-interference in each other's domestic affairs. These principles stem largely from the fact that member states of ASEAN have fought anti-colonial wars with Western European powers and wars of independence with the US and Japan, for example. Thus, traditional norms form part of the intersubjective systemic structure of ASEAN that has contributed to its collective identity. This collective identity enabled ASEAN to be more assertive in dealing with the EU's pressures on human rights and democracy, particularly on the issue of Myanmar/Burma. Even so, it was also through the process of strategic interaction with the EU on human rights that ASEAN's attitude on the issue has been transformed. Specifically, it has accommodated human rights as part of the organization's fundamental principles, which is enshrined in the ASEAN Charter. Overall, ASEAN-EU relations and the ASEM process have over the years expanded the scope of their interregional interactions. However, it remains to be seen whether in the long run such interactions would indeed meaningfully and substantively contribute to regional and global good governance. 


\section{References}

ASEAN. (2007a). Nuremberg Declaration on an ASEAN-EU Enhanced Partnership. Retrieved November 26, 2010, from http://www.aseansec.org/20693.pdf

ASEAN. (2007b). Plan of Action to Implement the Nuremberg Declaration on ASEAN-EU Enhanced Partnership. Retrieved November 26, 2010, from http://www.aseansec.org/2122.pdf

ASEAN. (2009). ASEAN-European Union Dialogue. Retrieved November 25, 2010, from http://www.aseansec.org/5612.htm

ASEAN. (2010). Overview of ASEAN-EU Dialogue Relations. Retrieved November 25, 2010, from http://www.aseansec.org/23216.htm

ASEM. (1996). Chairman's Statement, Asia Europe Meeting, 2 March 1996, Bangkok. Retrieved November 27 , 2010, from www.europa.eu.int/external_relations/asem/asem_summits/asem1.htm

ASEM. (1998). Chairman's Statement, Second Asia Europe Meeting, 4 April 1998, London. Retrieved November 27, 2010, from www.europa.eu.int/comm/external_relations/asem/asem_summits/asem2.htm

Bellamy, A. J. (2005). Introduction: International Society and the English School. In A. J. Bellamy (Ed.), International Society and Its Critiques (pp. 1-28). New York, NY: Oxford University Press.

Bull, H. (1977). The Anarchical Society: A Study of Order and World Politics. Houndmills: McMillan.

Chaban, N. (2009). 'Soft Power' and 'Human Face': Images of the EU as a Social, Environmental, and Developmental Actor in the Asian Media and Public Discourses. In M. H. N. Chaban (Ed.), The EU Through the Eyes of Asia: New Cases, New Findings (Vol. 2, pp. 159-216). Singapore: World Scientific. http://dx.doi.org/10.1142/9789814289894_0006

Council of the European Union. (2009). 17th ASEAN-EU Ministerial Meeting Joint Chairmen's Statement. Retrieved November 26, 2010, from http://www.consillium.europa.eu

Dosch, J. (2003). Changing security cultures in Europe and Southeast Asia: Implications for inter-regionalism. Asia Europe Journal, 1, 483-501. http://dx.doi.org/10.1007/s10308-003-0051-y

EC Communications. (2004). A New Partnership with Southeast Asia. European Commission, External Relations. Luxembourg: Office for Offical Publications of European Communities.

Holland, M. (2009). Assuming Superpower Status? Evolving Asian Perceptions of the EU as a Political and Economic Actor. In N. Chaban, M. Holland, \& P. Ryan (Eds.), The EU Through the Eyes of Asia: New Cases, New Findings (Vol. 2, pp. 125-158). Singapore: World Scientific.

Holland, M., Ryan, P., Nowak, A. Z., \& Chaban, N. (Eds.). (2007). The EU Through the Eyes of Asia: Media, Public and Elite Perceptions in China, Japan, Korea, Singapore and Thailand (Vol. 1). Singapore and Warsaw: Asia Europe Foundation, National Centre for Research in Europe, Ateneo de Manila University, and University of Warsaw. http://dx.doi.org/10.1142/9789814289894_0005

JCIE and University of Helsinki. (2006). "Overview" ASEM int its Tenth Year: Looking Back, Looking Forward. Japan Centre for International Exchange and University of Helsinki. Tokyo: JCIE.

Manea, M. G. (2008). Human rights and the interregional dialogue between Asia and Europe: ASEAN-EU relations and ASEM. The Pacific Review, 21(3), 369-396. http://dx.doi.org/10.1080/09512740802134257

Ong, K. Y. (2007). One ASEAN: a partner for Europe. Asia Europe Journal, 5, 443-445. http://dx.doi.org/10.1007/s10308-007-0143-1

Petchisri, A. (2004). How European integration is perceived in Asia. Asia Europe Journal, (2), 373-386. http://dx.doi.org/10.1007/s10308-004-0104-x

Ramos, F. V. (2006). Europe is where the future is being shaped. Asia Europe Journal, 4, 115-119. http://dx.doi.org/10.1007/s10308-005-0035-1

Robles, A. C. (2004). The Political Economy of Interregional Relations: ASEAN and the EU. Aldershot and Burlington: Ashgate.

Robles, A. C. (2007a). FTAs in Asia-Europe Relations. Retrieved November 22, 2010, from http://ipdprojects.org

Robles, A. C. (2007b). CARAM Asia. Retrieved November 22, 2010, from http://www.caramasia.org/enews/2007/JUne/critic_EU_ASEAN_FTA.pdf 
Robles, A. C. (2008a). The Asia-Europe Meeting: The theory and practice of interregionalism. Abingdon and New York: Routledge.

Robles, A. C. (2008b). The EU and ASEAN: Learning from the failed EU-Mercosur FTA Negotiations. ASEAN Economic Bulliten, 25(8), 334-344. http://dx.doi.org/10.1355/AE25-3F

Robles, A. C. (2008c). EU FTA Negotiations with SADC and Mercosur: integration into world economy or market access for EU firms?. Third World Quarterly, 29(1), 181-197. http://dx.doi.org/10.1080/01436590701726608

Severino, R. C. (2003). Regional Integration in Europe and Asia: The future of Asean economic integration . Asia Europe Journal, 1, 475-479. http://dx.doi.org/10.1007/s10308-003-0058-4

Severino, R. C. (2008). The emerging region of East Asia. Asia Europe Journal, 5, 447-454. http://dx.doi.org/10.1007/s10308-007-0134-2

Tze, E. T. (2005). Towards an Asian Union. Asia Europe Journal, (3), 137-140. http://dx.doi.org/10.1007/s10308-005-0140-1

Yeo, L. H. (2003). Asia and Europe: The development and different dimensions of ASEM. London and New York: Routledge.

Yeo, L. H. (2009). Political Cooperation Between the EU and ASEAN: Searching for Long-Term Agenda and Joint Projects. In P. J. Welfens, C. Ryan, S. Chirativhat, \& F. Kipping, EU-ASEAN: Facing Economic Globalisation (pp. 45-56). Verlag, Berlin, Heidelberg: Springer.

Yi, S., \& Chaban, N. (2009). ASEM under the Radar: Media Portrayals of Asia-Europe Meeting in Asia. In M. H. N. Chaban (Ed.), The EU Through the Eyes of Asia: New Cases, New Findings (Vol. 2, pp. 217-246). Singapore: World Scientific. 